\title{
Kidney IGF-I mRNA in initial renal hypertrophy in experimental diabetes in rats
}

\author{
A. Flyvbjerg ${ }^{1}$, K. E. Bornfeldt ${ }^{3}$, S. M. Marshall ${ }^{1}$, H.J. Arnqvist ${ }^{4}$ and H. Ørskov ${ }^{2}$ \\ ${ }^{1}$ Second University Clinic of Internal Medicine, Aarhus Kommunehospital, ${ }^{2}$ Institute of Experimental Clinical Research, University \\ of Aarhus, Aarhus, Denmark, Departments of ${ }^{3}$ Pharmacology and ${ }^{4}$ Internal Medicine, Linköping University, Linköping, Sweden
}

\begin{abstract}
Summary. It has recently been demonstrated that immunoassayable kidney insulin-like growth factor I concentration increases $24-48 \mathrm{~h}$ after induction of diabetes, preceding the initial renal hypertrophy. To elucidate whether this increase is due to increased local production we studied rat kidney insulin-like growth factor I gene expression during the first four days after induction of streptozotocin diabetes. Eighteen hours after injection with streptozotocin the diabetic animals were divided into two groups, one of which was treated with insulin, and daily for four days animals from each group were taken out for investigation. After four days the wet kidney weight had increased from baseline by $20 \%$ (from $687 \pm 23$ to $827 \pm 6 \mathrm{mg}$ (mean $\pm \mathrm{SEM}$ ), $p<0.01$ ) in the untreated diabetic group, while no significant increase occurred in the insulin-treated group (687 \pm 23 vs $732 \pm 21 \mathrm{mg}$, NS). Kidney insulin-like growth factor I increased rapidly from baseline, the rise amounting to $52 \%$ after $48 \mathrm{~h}$ (from $271 \pm 11$ to $411 \pm 32 \mathrm{ng} / \mathrm{g}, p<0.01$ ) with a decline to control level on
\end{abstract}

day four in the untreated diabetic group. Kidney insulin-like growth factor I remained unchanged in the insulin-treated diabetic group. Insulin-like growth factor I mRNA was measured by solution-hybridization assay. No differences were found in kidney insulin-like growth factor I mRNA between the two diabetic groups over the study period, while in liver, insulin-like growth factor I mRNA tended to be lower on day four in diabetic rats when compared to insulin-treated rats $(p=0.07)$. These results show that the increase in kidney insulin-like growth factor I during initial renal hypertrophy in experimental diabetes is not associated with an elevated level of kidney insulin-like growth factor I mRNA and suggest that other, possibly translational, mechanisms are responsible for insulin-like growth factor accumulation in the kidney.

Key words: Renal hypertrophy, insulin-like growth factor I, insulin-like growth factor I mRNA, streptozotocin diabetes.
Renal hypertrophy and hyperfiltration are early manifestations of human and experimental diabetes [1-3] which may contribute to the later development of diabetic nephropathy [4]. Induction of experimental diabetes causes a rapid increase in renal size accompanied by increases in total kidney RNA and protein demonstrable $36 \mathrm{~h}$ after the onset of glycosuria, whereas DNA content remains unchanged for at least the first eight days [2]. This diabetic renal hypertrophy is preceded by a rise in extractable renal tissue concentration of insulin-like growth factor I (IGF-I), which reaches a peak $48 \mathrm{~h}$ after induction of diabetes $[3,5]$.

It is not known whether this increase in kidney IGF-I concentration is due to increased uptake from the blood or to local production of IGF-I. Traditionally, the liver has been considered to be the main site of IGF-I synthesis mainly under the control of growth hormone [6]. However, the increase in kidney IGF-I after induction of diabetes is accompanied by little or no change in circulating levels of IGF-I $[3,5]$. RIA of acetic acid tissue extracts has demonstrated the presence of IGF-I in many tissues including the kidney and liver [7] and recently the gene expression for IGF-I, measured as tissue content of mRNA for IGF-I (IGF-I mRNA), has been demonstrated in many tissues including the kidney [8,9].

Renal hypertrophy following growth hormone (GH) treatment of hypophysectomized rats and compensatory renal growth subsequent to unilateral nephrectomy are both accompanied by increased levels of extractable $[3,5$, $7,10-12]$ and immunostainable kidney IGF-I $[11,12]$. $\mathrm{GH}$-treatment induces increased renal IGF-I mRNA expression, whereas unilateral nephrectomy is followed by unchanged, steady-state IGF-I mRNA levels [12]. These results suggest that IGF-I may act as a renotropic agent through both transcriptional and translational mechanisms.

In this study we investigated the mechanism responsible for kidney IGF-I accumulation in experimental diabetes by measurement of kidney IGF-I mRNA during the initial renal growth following induction of diabetes. 


\section{Materials and methods}

\section{Animals}

Male Wistar rats (Møllegaards Avlslab., Eiby, Denmark) with a mean body weight of $195 \mathrm{~g}$ (range 185-204 g) were studied. Rats were housed three per cage in a room with $12: 12 \mathrm{~h}$ (06.0018.00 hours) artificial light cycle, temperature $21 \pm 2^{\circ} \mathrm{C}$ and humidity $55 \pm 2 \%$. The animals had free access to standard rat chow (AItromin, Lage, FRG) and tap water throughout the experiment. The animals were randomised into three groups matched for body weight: (1) control animals $(n=12)$; (2) diabetic animals, no insulin treatment $(n=24)$ and (3) diabetic animals, insulin-treated $(n=24)$. Diabetes was induced on day 0 by i.v. injection of streptozotocin (STZ) $(55 \mathrm{mg} / \mathrm{kg}$ body weight) in acidic $0.154 \mathrm{~mol} / \mathrm{l} \mathrm{NaCl}(\mathrm{pH} 4.0)$ following $12 \mathrm{~h}$ of food deprivation. Eighteen hours after administration of STZ, and daily thereafter, the animals were weighed, urinalysis was performed for glucose and ketones using Neostix 4 (Ames Limited, Stoke Poges, Slough, UK) and tail-vein blood glucose determined by Haemoglucotest 1-44 and Reflolux II reflectance meter (Boehringer-Mannheim, Mannheim, FRG). Insulin treatment with a very long-acting, heat-treated Ultralente Insulin (Novo, Bagsvaerd, Denmark) was initiated $18 \mathrm{~h}$ after administration of STZ when all animals had blood glucose levels above $15 \mathrm{mmol} / 1$. Insulin was given in an initial dose of 4-6 U, followed by 1-2 U daily thereafter depending on blood glucose values.

Each day from day 1 to 4 , six animals from each of the two diabetic groups were studied in addition to six control animals on days 0 and 4 . Under sodium barbital anaesthesia $(50 \mathrm{mg} / \mathrm{kg})$ blood was drawn from the retro-orbital venous plexus and serum stored at $-20^{\circ} \mathrm{C}$ for later determination of IGF-I. Both kidneys were removed and rapidly cleaned. The left kidneys were immediately frozen in liquid nitrogen for later analysis of IGF-I mRNA and the right weighed, frozen and subsequently used for IGF-I determination by acetic acid extraction. In addition, two liver pieces were removed and immediately frozen for later IGF-I mRN A and IGF-I analysis.

\section{Preparation of total nucleic acid}

Total nucleic acid (TNA) was prepared according to Durnam and Palmiter [13]. In short, the frozen tissues were homogenized in a sodium dodecyl sulphate (SDS)-containing buffer with a polytron PT 1020 350D (Kinematica GmbH, Luzern, Switzerland) for $8 \mathrm{~s}$. The samples were digested with proteinase $K$ and extracted with phenol and chloroform. The TNA was precipitated by addition of ethanol, and measured by spectrophotometry at $260 \mathrm{~nm}$, while the DNA-content was measured by fluorimetry [14].

\section{Solution-hybridization of IGF-I $m R N A$}

Levels of IGF-I mRNA were analysed using a $\left.{ }^{35} \mathrm{~S}\right) \mathrm{UTP}$-labelled RNA probe. The probe was complementary to 153 basepairs in exon 3 (by analogy to the human gene) of the mouse IGF-I gene as described previously [8]. This sequence has $92 \%$ homology with the corresponding rat sequence, and it detects the different forms of IGF-I mRNA which have recently been described in rat tissues [15]. The RNA probe, prepared according to the method of Melton [16], was hybridized to TNA samples at $70^{\circ} \mathrm{C}$ for $16 \mathrm{~h}$ as described by Mathews et al. [8]. Hybridization was performed in $40 \mu \mathrm{l}$ of $0.6 \mathrm{~mol} / \mathrm{l}$ $\mathrm{NaCl}, 20 \mathrm{mmol} / 1$ Tris- $\mathrm{HCl}$ (pH 7.5), $4 \mathrm{mmol} / \mathrm{l}$ EDTA, $0.1 \%$ (weight/volume) SDS, $7.5 \mathrm{mmol} / \mathrm{l}$ dithiothreitol (DTT), $25 \%(\mathrm{v} / \mathrm{v})$ formamide and $10,000 \mathrm{cpm}$ probe/incubation (specific activity; approximately $1.2 \times 10^{15} \mathrm{cpm} / \mathrm{g}$ probe). The samples were exposed to RNAses and the hybrids precipitated with $100 \mu 1$ of $6 \mathrm{~mol} / 1$ trichloroacetic acid, collected on glass microfibre filters and analysed in a liquid scintillation counter (LKB, 1217 Rackbeta, Turku, Finland). The radioactivity of the TNA samples was compared with that of a standard curve constructed from incubations with a rat liver TNA sample with a known amount of IGF-I mRNA. The level of mRNA in the TNA standard sample was originally determined using known amounts of in vitro synthesized RNA complementary to the probe. A standard curve was included in each assay and the samples were analysed in triplicate. The intra-assay and the inter-assay coefficient of variation of the method was $22 \%$ and $20 \%$ respectively, when a sample with a very low concentration of IGF-I mRNA (13.1 pmol/1 IGF-I mRNA) was analysed six times.

\section{IGF-I determination}

Tissue extraction of renal and hepatic IGF-I was performed in $1 \mathrm{~mol} / \mathrm{l}$ acetic acid as described by D'Ercole [7]. After extraction and lyophilization the samples were redissolved in $40 \mathrm{mmol} / \mathrm{l}$ phosphate buffer $(\mathrm{pH} 8.0)$ and stored at $-20^{\circ} \mathrm{C}$ until analysis [3, 5]. Serum was extracted in acetic acid-methanol $[3,5]$. IGF-I was determined by RIA using IGF-I antibody UB 286 (raised by L. E. Underwood and J.J.van Wyk, Paediatric Endocrinology, University of North Carolina, Chapel Hill, NC, USA) donated by the US National Hormones and Pituitary Program. A full amino-acid sequence analogue (Amgen Biologicals, Thousand Oaks, Calif., USA) was used for standards and iodination $[3,5]$.

\section{Chemicals}

SDS and DTT were obtained from Sigma Chemical Co., (St. Louis, Mo., USA) and Proteinase K from Merck, (Darmstadt, FRG). Phenol (liquified) was obtained from Fisher Scientific, (Fair Lawn, NJ, USA). $\left({ }^{35}\right.$ S) UTP and IGF-I were obtained from Amersham International plc., (Amersham, Buckinghamshire, UK). Chemicals for probe synthesis were obtained from Promega Inc., (Madison, Wi., USA) and RNase A, RNase T1 and herring sperm DNA were obtained from Boehringer. Insta-Gel was obtained from Packard, (Groningen, The Netherlands) and formamide was from IBI, (New Haven, Ct., USA).

\section{Statistical analysis}

Differences between groups were analysed by one-way analysis of variance (ANOVA) in combination with the Bonferroni test for multiple comparisons and unpaired Student's $t$-test. Significant differences between untreated and insulin-treated animals are shown in the figures, while the significances of changes within groups from day 0 level are given in the text. Results are expressed as mean \pm SEM.

\section{Results}

Metabolic parameters and body weight (Fig. l)

All animals given STZ developed diabetes with blood glucose concentrations above $15 \mathrm{mmol} / \mathrm{l}$ after $18 \mathrm{~h}$ (Fig. $1 \mathrm{a}$ ). Blood glucose in the untreated diabetic animals stabilized around $25 \mathrm{mmol} / \mathrm{l}$ after $24 \mathrm{~h}$ and remained at that level for the duration of the study, whilst in the insulin-treated group blood glucose fell to around $6 \mathrm{mmol} / 16 \mathrm{~h}$ after the first injection and remained stable thereafter at levels comparable to non-diabetic control animals (Fig. 1a). All untreated animals had glycosuria of $>111 \mathrm{mmol} / \mathrm{l}$ and none of the animals exhibited ketonuria at any time during the study.

Body weight changes are shown in Figure 1b. Untreated diabetic animals had a weight loss of $4 \%$ on day 2 from initial level $(p<0.01)$, returning towards initial levels 


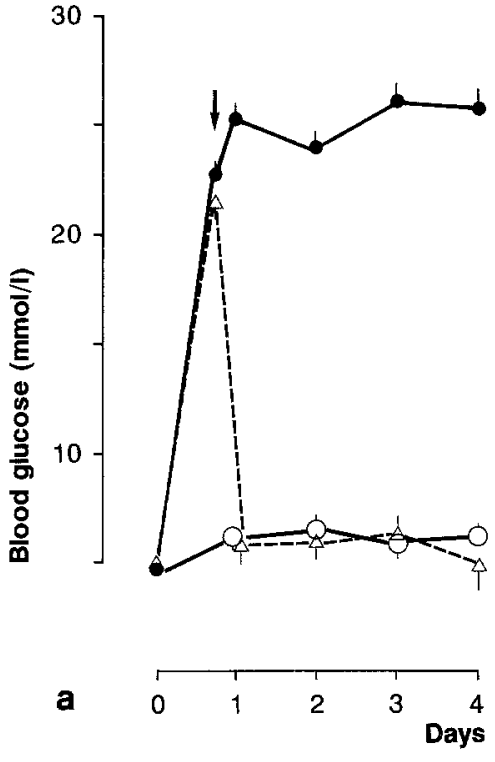

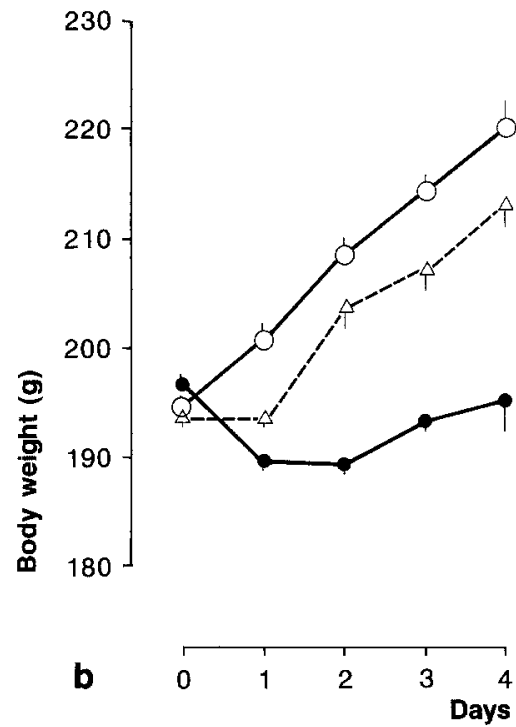

Fig. 1a,b. Blood glucose (a) and body weight (b) during the four experimental days in control animals $(\circ-0)$, untreated diabetic $(\bullet)$ and insulin-treated diabetic animals $\left(\Delta^{---} \Delta\right)$. Insulin treatment with a very long-acting, heat-treated Ultralente Insulin was initiated $18 \mathrm{~h}$ after administration of streptozotocin, as indicated by the arrow. Values are mean \pm SEM. Blood glucose and body weight values include all animals on day 0 and from day 1 to 4 each point represents the remaining animals i.e. $n=24,18,12,6$ in each of the diabetic groups. For control animals each point represents $n=6$ on days 3 and 4 . Insulin-treated animals did not lose weight, and had, after the initiation of insulin treatment, a weight gain parallel to that seen in non-diabetic control animals (Fig. 1b).

\section{Kidney growth (Fig. 2)}

Kidney weight in the untreated group increased rapidly after induction of diabetes, significant differences from baseline being seen by day $3(p<0.02)$ (Fig. 2) and after 4 days wet kidney weight had increased from baseline by $20 \%$ (from $687 \pm 23$ to $827 \pm 6 \mathrm{mg}$ ) $(p<0.01$ ). Kidney weight in the untreated group was significantly greater $(p=0.01)$ than in the insulin-treated group after $24 \mathrm{~h}$ and throughout the observation period. The kidney weight of the control animals did not change significantly from day 0 to 4 , being identical to kidney weight of insulintreated diabetic animals (Fig. 2).

\section{Kidney IGF-I levels by RIA (Fig.3a)}

The kidney IGF-I concentration (ng/g kidney tissue) increased rapidly in the untreated diabetic group reaching a peak 2 days after induction of diabetes, with an increase of $52 \%$ from the initial level (from $271 \pm 11$ to $411 \pm 32 \mathrm{ng} / \mathrm{g}$, $p<0.01)$. The kidney IGF-I concentration thereafter declined to control values on day 4 . There was no change in renal IGF-I concentration in either insulin-treated diabetic or control animals during the study period. Kidney IGF-I levels were significantly higher in the untreated group on day 2 and 3 when compared to their insulintreated counterpart (Fig. 3 a).

\section{Kidney IGF-I mRNA levels (Fig. $3 b$ )}

IGF-I mRNA expressed as amount of IGF-I mRNA/DNA $\left(\mathrm{a}\left(10^{-18}\right) \mathrm{mol} / \mu \mathrm{g}\right)$, was quantified using solution-hybridization assay as described in Materials and methods. Figure $3 \mathrm{~b}$ shows that IGF-I mRNA levels were unchanged and similar in both diabetic groups and in nondiabetic controls during the first 4 days of diabetes.

\section{Hepatic IGF-ImRNA, extractable hepatic IGF-I and serum IGF-I levels (Table 1)}

No significant differences were found in liver IGF-I mRNA or IGF-I levels between the two diabetic groups during the study period, although liver IGF-I mRNA tended to be lower at day 4 in untreated diabetic rats when compared to the insulin-treated group $(p=0.07)$. Serum
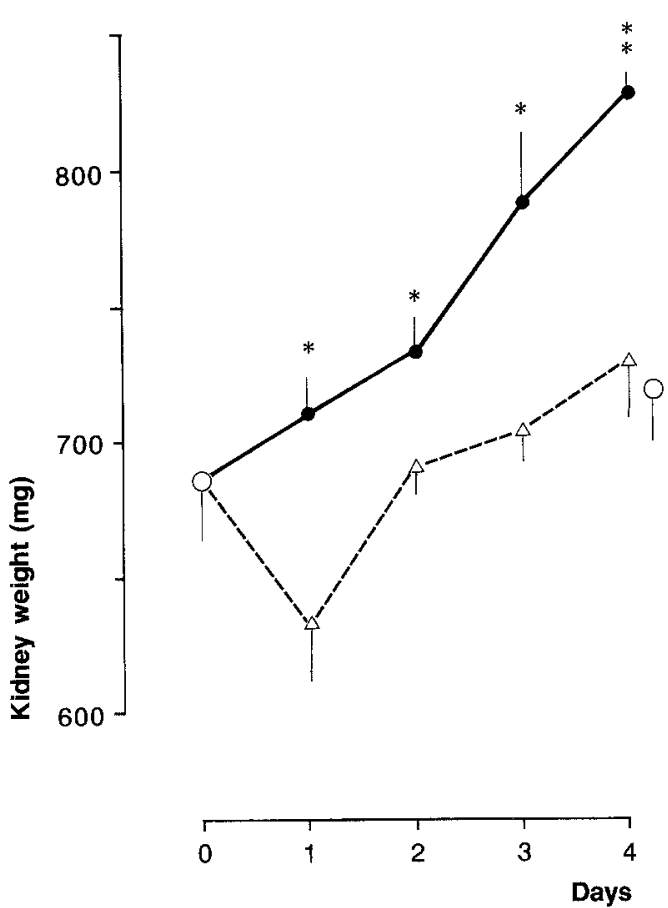

Fig. 2. Changes in kidney weight in streptozotocin-diabetic rats, untreated $(-)$ ) and insulin-treated $(\Delta--\Delta)$, over four days and in nondiabetic control rats day 0 and $4(0)$. $* p<0.05$, *** $p<0.01$ between untreated and insulin-treated diabetic animals. Values are given as mean \pm SEM. Every point represents 6 different animals 

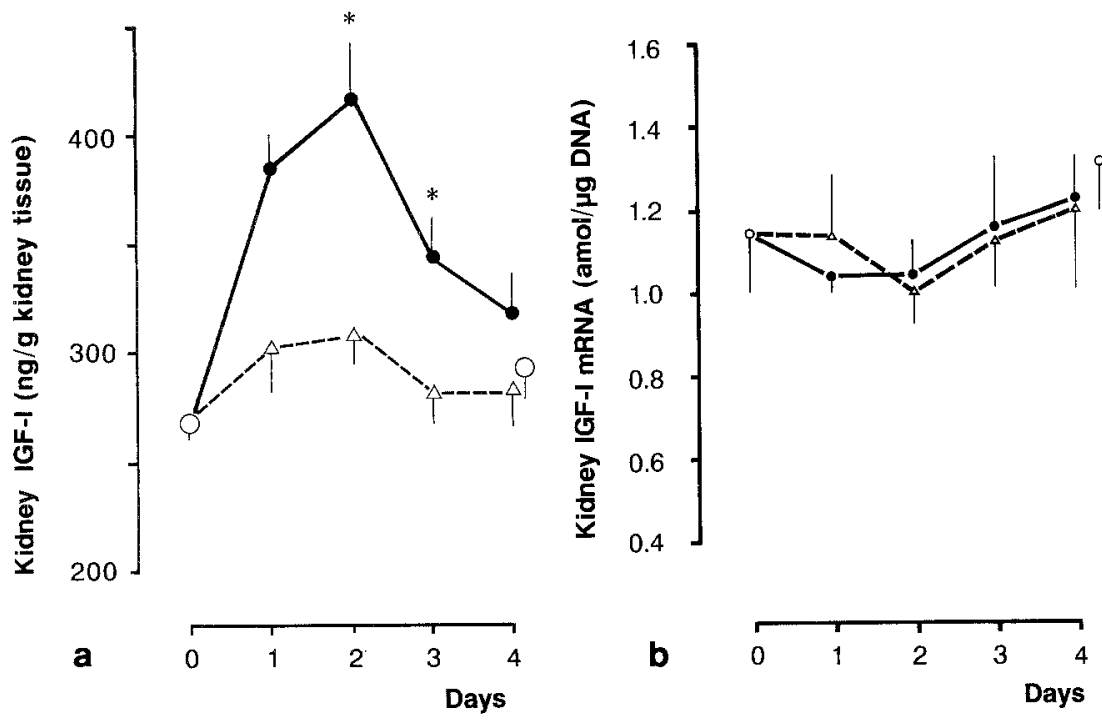

Fig. 3a, b. Kidney insulin-like growth factor I (IGF-I) (a) and kidney IGF-I mRNA (b) in control $(0)$, untreated diabetic $(\bullet)$ and insulin-treated diabetic animals $(\triangle--\triangle)$ during the four experimental days. ${ }^{*} p<0.05$ between untreated and insulin-treated diabetic animals. Values are mean $\pm \mathrm{SEM}, n=6$ for kidney IGF-I values and $n=5$ for kidney IGF-I mRNA

IGF-I was decreased in untreated diabetic animals on day 2 when compared to their insulin-treated counterpart $(p<0.01)$, while no difference was found on day 4 (Table 1).

\section{Discussion}

The demonstration of IGF-I mRNA in kidney in this and other studies $[8,9,12,17,18]$ suggests that the kidney is capable of synthesizing IGF-I. The level of kidney IGF-I mRNA was approximately 100 -fold lower than that in liver. Local production of immunoreactive IGF-I has been demonstrated in several types of cells including kidney mesangial cells $[19,20]$. In this study we found unchanged levels of IGF-I mRNA in diabetic kidneys although immunoreactive IGF-I concentration was increased. Two recent reports have shown decreased kidney IGF-I mRNA levels in experimental diabetes of four [17] and seven days duration [18]. The different results may be due to differences in severity of the diabetic state. Although the degree of renal hypertrophy is linearly dependent on blood glucose concentration, a too severe metabolic derangement, as indicated by extreme hyperglycaemia or ketonuria, diminishes or even abolishes the kidney growth [21-23]. We found that IGF-I mRNA in liver and IGF-I in serum tended to be lower in untreated diabetic rats compared to insulin-treated rats. In rats with a more severe metabolic upset than in this present study IGF-I mRNA in liver [17, $18,24]$ and IGF-I in serum $[18,24]$ were reduced. Serum IGF-I originates mainly from the liver [25] and these results suggest that the lowered IGF-I mRNA in liver is accompanied by a decrease in synthesis of circulating IGF-I. The finding of unaffected or decreased IGF-I mRNA levels in the diabetic kidney suggests that the local production of IGF-I is unchanged or decreased in diabetic kidneys undergoing initial renal hypertrophy.

In two other situations with rapid initial renal growth: administration of $\mathrm{GH}$ to hypophysectomized rats and unilateral nephrectomy, similar rises in extractable and immunostainable renal IGF-I concentration and kidney weights are seen $[3,5,7,10-12]$. Consistent with a GHmediated induction of IGF-I synthesis, systemic GHtreatment enhances kidney levels of IGF-I mRNA, immunostainable IGF-I and kidney size [12]. Renal growth following unilateral nephrectomy has been reported to be accompanied by a "relative" increase in renal IGF-I mRNA using "dot-blot" analysis [26], however, when using solution-hybridization assay with higher specificity and sensitivity [27] no changes in steady-state IGF-I mRNA level in kidneys from nephrectomized rats were seen [12].

Table 1. Hepatic insulin-like growth factor I (IGF-I) mRNA, extractable hepatic IGF-I and serum IGF-I in untreated and insulin-treated rats on day 2 and day 4 and in non-diabetic control rats on day 4 . Values are given as mean \pm SEM. Numbers in parentheses indicate the number of samples analysed

\begin{tabular}{|c|c|c|c|c|c|c|}
\hline & \multicolumn{2}{|c|}{$\begin{array}{l}\text { IGF-I mRNA } \\
\left(\mathrm{a}\left(10^{-18}\right) \mathrm{mol} / \mu \mathrm{g} \text { DNA }\right)\end{array}$} & \multicolumn{2}{|c|}{$\begin{array}{l}\text { IGF-I } \\
\text { (ng/g liver) }\end{array}$} & \multicolumn{2}{|c|}{$\begin{array}{l}\text { Serum IGF-I } \\
(\mu \mathrm{g} / 1)\end{array}$} \\
\hline & Day 2 & Day 4 & Day 2 & Day 4 & Day 2 & Day 4 \\
\hline Untreated diabetic rats & $\begin{array}{l}117 \pm 24 \\
(6)\end{array}$ & $\begin{array}{l}98 \pm 22 \\
(5)\end{array}$ & $\begin{array}{l}47 \pm 4 \\
(6)\end{array}$ & $\begin{array}{l}57 \pm 6 \\
(6)\end{array}$ & $\begin{array}{l}733 \pm 80^{a} \\
(6)\end{array}$ & $\begin{array}{l}941 \pm 40 \\
(6)\end{array}$ \\
\hline Insulin-treated diabetic rats & $\begin{array}{l}171 \pm 22 \\
(6)\end{array}$ & $\begin{array}{l}184 \pm 37 \\
(5)\end{array}$ & $\begin{array}{l}54 \pm 5 \\
(6)\end{array}$ & $\begin{array}{l}54 \pm 7 \\
(6)\end{array}$ & $\begin{array}{l}1115 \pm 88 \\
(6)\end{array}$ & $\begin{array}{l}882 \pm 33 \\
(6)\end{array}$ \\
\hline
\end{tabular}

${ }^{a} p<0.02$ between untreated and insulin-treated diabetic rats on day 2 
The solution-hybridization assay used in the present study is sensitive enough to detect small differences in IGF-I mRNA [13]. The unaltered level of IGF-I mRNA in renal hypertrophy in experimental diabetes seems to indicate that the local production at transcriptional level is unchanged. The major regulation of renal IGF-I production in GH-induced renal hypertrophy has been found to be pre-translatory [12]. However, it cannot be excluded that the IGF-I accumulation in the diabetic kidney is due to enhanced translatory regulation, as it has been suggested for the IGF-I accumulation in post-nephrectomy renal growth [12].

Alternatively, other mechanisms may account for the increase in immunoreactive IGF-I in diabetic kidneys. Circulating or locally produced IGF-I could be trapped more efficiently, for example via enhanced receptor-mediated binding to cells or via an altered pattern of IGF-I binding protein expression. Finally, sequestration of IGF-I within tubules and collecting ducts or decreased breakdown of the peptide could be responsible for the IGF-I accumulation in the diabetic kidney.

Acknowledgements. We thank Dr. G. Norstedt for generously providing the insulin-like growth factor I (IGF-I) RNA probe. We are indebted to Ms. K. Nyborg and Ms. R. Gidlöf for skilled technical assistance and to Ms. A. Andersen for secretarial help. Furthermore, we are grateful to Drs. L.E. Underwood and J.J.van Wyk and the National Hormone and Pituitary Program for gifts of IGF-I antibody. This study was supported by grants from the Danish Diabetes Association, the Danish Medical Research Council (no. 12-7713), the Ruth Kønig Petersens Foundation and the Swedish Medical Research Council (no. 04952). S. M. Marshall held a British Medical Research Council Travelling Fellowship.

\section{References}

1. Mogensen CE, Andersen MJF (1973) Increased kidney size and glomerular filtration rate in early juvenile diabetes. Diabetes 22 : 706-712

2. Seyer-Hansen K (1976) Renal hypertrophy in streptozotocindiabetic rats. Clin Sci 51: 551-555

3. Flyvbjerg A, Thorlacius-Ussing O, Næraa R, Ingerslev J, Ørskov $\mathrm{H}$ (1988) Kidney tissue somatomedin C and initial renal growth in diabetic and uninephrectomized rats. Diabetologia 31: 310-314

4. Mogensen CE (1986) Early glomerular hyperfiltration in insulindependent diabetics and late nephropathy. Scand J Clin Lab Invest 46: 201-206

5. Flyvbjerg A, Frystyk J, Thorlacius-Ussing O, Ørskov H (1989) Somatostatin analogue administration prevents increase in kidney somatomedin $\mathrm{C}$ and initial renal growth in diabetic and uninephrectomized rats. Diabetologia 32: 261-265

6. Daughaday WH, Hall K, Raben MS, Salmon WD Jr, Van den Brande JL, Van Wyk JJ (1972) Somatomedin: proposed designation for sulphation factor. Nature 235: 107

7. D'Ercole AJ, Stiles AD, Underwood LE (1984) Tissue concentration of somatomedin $\mathrm{C}$ : further evidence for multiple sites of synthesis and paracrine or autocrine mechanisms of action. Proc Natl Acad Sci USA 81: 935-939

8. Mathews LS, Norstedt G, Palmiter RD (1986) Regulation of insulin-like growth factor I gene expression by growth hormone. Proc Natl Acad Sci USA 83: 9343-9347

9. Murphy LJ, Bell GI, Frisen HG (1987) Tissue distribution of insulin-like growth factor I and II ribonucleic acid in the adult rat. Endocrinology 120: 1279-1282
10. Stiles AD, Sosenko IRS, D'Ercole AJ, Smith BT (1985) Relations of kidney tissue somatomedin-C/insulin-like growth factor I to postnephrectomy renal growth in the rat. Endocrinology 117:2397-2401

11. Andersen GL, Skottner A, Jennische E (1988) Immunocytochemical and biochemical localization of insulin-like growth factor I in the kidney of rats before and after uninephrectomy. Acta Endocrinol (Copenh) 119:555-560

12. Lajara R, Rotwein P, Bortz JD, Hansen VA, Sadow JL, Betts CR, Rogers SA, Hammerman MR (1989) Dual regulation of insulinlike growth factor I expression during renal hypertrophy. Am J Physiol 257: F252-F261

13. Durnam DM, Palmiter RD (1983) A practical approach for quantitating specific mRNAs by solution hybridization. Anal Biochem 131: 385-393

14. Labarca C, Paigen K (1980) A simple, rapid and sensitive DNA assay procedure. Anal Biochem 102: 344-352

15. Shimatsu A, Rotwein P (1987) Mosaic evolution of the insulinlike growth factors. Organization, sequence, and expression of the rat insulin-like growth factor I gene. J Biol Chem 262: 7894-7900

16. Melton DA, Krieg PA, Rebagliati MR, Maniatis T, Zinn K, Green MR (1984) Efficient in vitro synthesis of biologically active RNA and RNA hybridization probes from plasmids containing a bacteriophage SP6 promotor. Nucl Acids Res 12: $7035-7056$

17. Bornfeldt KE, Arnqvist HJ, Enberg B, Mathews LS, Norstedt G (1989) Regulation of insulin-like growth factor-I and growth hormone receptor gene expression by diabetes and nutritional state in rat tissues. J Endocrinol 122: $651-656$

18. Fagin JA, Roberts CT, LeRoith D, Brown AT (1989) Coordinate decrease of tissue insulin-like growth factor I posttranscriptional alternative mRNA transcripts in diabetes mellitus. Diabetes 38 : $428-434$

19. Clemmons DR, Underwood LE, Van Wyk JJ (1981) Hormonal control of immunoreactive somatomedin production by cultured human fibroblasts. J Clin Invest 67: 10-19

20. Conti FG, Striker LJ, Elliot SJ, Andreani D, Striker GE (1988) Synthesis and release of insulin like growth factor I by mesangial cells in culture. Am J Physiol 255: F 1214-F 1219

21. Seyer-Hansen K (1977) Renal hypertrophy in experimental diabetes: Relation to severity of diabetes. Diabetologia 13: $141-143$

22. Hostetter TH, Troy JL, Brenner BM (1981) Glomerular hemodynamics in experimental diabetes mellitus. Kidney Int 19: $410-415$

23. Seyer-Hansen K (1983) Renal hypertrophy in experimental diabetes mellitus. Kidney Int 23: 643-646

24. Goldstein S, Sertich GJ, Levan KR, Phillips LS (1988) Nutrition and somatomedin. XIX. Molecular regulation of insulin-like growth factor-1 in streptozotocin-diabetic rats. Molec Endocrinol 2: 1093-1100

25. Froesch ER, Schmid S, Schwander J, Zapf J (1985) Actions of insulin-like growth factors. Ann Rev Physiol 47:443-467

26. Fagin JA, Melmed S (1987) Relative increase in insulin-like growth factor I messenger ribonucleic acid levels in compensatory renal hypertrophy. Endocrinology 120: 718-724

27. Rotwein P, Burgess SK, Milbrandt JD, Krause JE (1988) Differential expression of insulin-like growth factor genes in rat central nervous system. Proc Natl Acad Sci USA 85:265-269

Received: 25 September 1989

and in revised form: 12 February 1990

Dr. A. Flyvbjerg

Second University Clinic of Internal Medicine

Aarhus Kommunehospital

DK-8000 Aarhus C

Denmark 